University of Chicago Law School

Chicago Unbound

Public Law and Legal Theory Working Papers

Working Papers

2008

\title{
Guarding the Guardians: Judicial Councils and Judicial Independence
}

Nuno Garoupa

Tom Ginsburg

Follow this and additional works at: https://chicagounbound.uchicago.edu/public_law_and_legal_theory

Part of the Law Commons

Chicago Unbound includes both works in progress and final versions of articles. Please be aware that a more recent version of this article may be available on Chicago Unbound, SSRN or elsewhere.

\section{Recommended Citation}

Nuno Garoupa \& Tom Ginsburg, "Guarding the Guardians: Judicial Councils and Judicial Independence" (University of Chicago Public Law \& Legal Theory Working Paper No. 250, 2008).

This Working Paper is brought to you for free and open access by the Working Papers at Chicago Unbound. It has been accepted for inclusion in Public Law and Legal Theory Working Papers by an authorized administrator of Chicago Unbound. For more information, please contact unbound@law.uchicago.edu. 


\title{
CHICAGO
}

JOHN M. OLIN LAW \& ECONOMICS WORKING PAPER NO. 444

(2D SERIES)

Public LAW AND Legal THEORY WORKING PAPER NO. 250

\author{
GUARDING THE GARDIANS: \\ JUDICIAL COUNCILS AND JUDICIAL INDEPENDENCE
}

Nuno Garoupa and Tom Ginsburg

\section{THE LAW SCHOOL THE UNIVERSITY OF CHICAGO}

November 2008

This paper can be downloaded without charge at the John M. Olin Program in Law and Economics Working Paper Series: http://www.law.uchicago.edu/Lawecon/index.html and at the Public Law and Legal Theory Working Paper Series: http://www.law.uchicago.edu/academics/publiclaw/index.html and The Social Science Research Network Electronic Paper Collection. 


\section{Nuno Garoupa and Tom Ginsburg* \\ Guarding the Guardians: Judicial Councils and Judicial Independence}

This Article uses comparative evidence to inform the ongoing debate about the selection and discipline of judges. In recent decades, many countries around the world have created judicial councils, institutions designed to maintain an appropriate balance between judicial independence and accountability. Our Article has two aims. First, we provide a theory of the formation of judicial councils and identify some of the dimensions along which they differ. Second, we test the extent to which different designs of judicial council affect judicial quality. We find that there is little relationship between councils and quality. We also offer a positive explanation for why judicial councils nevertheless remain attractive institutions.

\footnotetext{
* Nuno Garoupa is Professor of Law, University of Illinois and Research Professor of Law, IMDEA (Madrid); Tom Ginsburg is Professor at the University of Chicago Law School. We thank Luciana Gross Cunha, Emilio Gerelli, James Gordley, F. Andrew Hanssen, Richard McAdams, Maria Angela Oliveira, Limor Riza, Larry Solum, Stefan Van Hemmen, and seminar participants at the American Economic Association meetings in Chicago (ISNIE Special Session on the Economics of the Judiciary), the Taormina International Conference in Searching for New Methods in Law and Economics, the Latin American and Caribbean Law and Economics Association meetings in Brasilia, the Royal Economic Society meetings in Coventry, and at the workshops in UAB Barcelona, University of Illinois College of Law, the University of Southern California Gould School of Law and the Hamburg Institute of Law and Economics. We are grateful to Rebecca Crouse, Sofia Garcia, Christopher Minelli, and Antonio Porto for research assistantship. The usual disclaimers apply.
} 


\section{Introduction}

The selection of judges is a central factor in most theories of judicial independence. ${ }^{1}$ Judges who are dependent in some way upon the person who appoints them cannot be relied upon to deliver neutral, legitimate, high-quality decisions. While there is near-universal consensus on this as a matter of theory, legal systems have devised a wide range of selection mechanisms in practice, often trying to balance independence with accountability through institutional design. The diversity of systems of judicial selection suggests that there is no consensus on the best manner to guarantee independence. $^{2}$

At the same time, there is a trend toward insulating judicial selection from partisan politics. In the United States, this is reflected in the growing scholarly consensus in favor of "merit selection." In other countries, it is reflected in the adoption of judicial

\footnotetext{
${ }^{1}$ There is a large body of literature on judicial independence and quality. See, e.g., Richard Epstein, The Independence of Judges: The Uses and Limitations of Public Choice, BYU L. REV., at 827 (1990); Paul Fenn \& Eli Salzberger, Judicial Independence: Some Evidence from the English Court of Appeal, 42 J.L. \& ECON. 831 (1999); F. Andrew Hannsen, Is There a Politically Optimal Level of Judicial Independence?, 94 AM. ECON. ReV. 712 (2004); Irving Kaufman, The Essence of Judicial Independence, 80 CoLuM. L. REV. 671 (1980); Daniel Klerman \& Paul Mahoney, The Value of Judicial Independence: Evidence from 18th Century England, 7 AM. L \& ECON. REv. 1 (2005); William Landes \& Richard Posner, The Independent Judiciary in an Interest-Group Perspective, 18 J.L. \& ECON. 875 (1975); J. Mark Ramseyer, The Puzzling (In)dependence of Courts, 23 J. LEGAL STUD. 721 (1994); J. Mark Ramseyer \& Eric Rasmusen, Judicial Independence in Civil Law Regimes: Econometrics from Japan, 13 J.L. ECON. \& ORG. 259 (1997); McNollgast, Conditions for Judicial Independence, 15 J. CONTEMP. LEgAL Issues 105 (2006); William H. Rehnquist, See in a Glass Darkly: The Future of the Federal Courts, WIS. L. REV. 1 (1993). For a more comparative perspective, see Josefina Calca de Temeltas, Commentary: Comparative Constitutional Approaches to the Rule of Law and Judicial Independence, 40 ST. LouIs U. L. J. 1997 (1996).

${ }^{2}$ See generally ApPointing Judges IN AN Age OF Judicial Power (Kate Malleson \& Peter H. Russell eds., 2006).

${ }^{3}$ Malia Reddick, Merit Selection: A Review of the Social Scientific Literature, 106 Dickerson L. ReV. 729 (2002) (providing summary of empirical evidence); Luke Bierman, Preserving Power in Picking Judges: Merit Selection for the New York Court of Appeals, 60 ALB. L. REV. 339 (1996) (advocating merit system for New York); Norman L. Greene, Perspectives on Judicial Selection Reform: The Need to Develop a Model Appointive Selection Plan for Judges in Light of Experience, 68 ALB. L. REV. 459 (2005) (merit system superior); Steven Zeidman, Keynote Address, Judicial Politics: Making the Case for Merit Selection, 68 ALB. L. REV. 713 (2005); Lawrence H. Avrill, Jr., Observations on the Wyoming Experience with Merit Selection of Judges: A Model for Arkansas, 17 U. ARK. LiTTLE Rock L.J. 281 (1995) (Arkansas); Sara S. Greene, et al., On the Validity and Vitality of Arizona's Judicial Merit Selection System: Past, Present, and Future, 34 Fordham URB. L.J. 239 (2007) (Arizona); Victoria Cecil, Merit Selection and Retention: The Great Compromise? Not Necessarily, 39 COURT REV. 20 (2002) (Florida); Jason J. Czarnezki, Essay, A Call for Change: Improving Judicial Selection Methods, OR. L. REv. 459 (2005) (Wisconsin); Lenore L. Prather, Judicial Selection: What is Right for Mississippi?, 72 Miss. C.L. ReV. 459 (2002) (Mississippi); Jona Goldschmidt, Merit Selection: Current Status Procedures, and Issues, 49 U. MiAmi L. REV. 1 (1994) (providing extensive history of merit selection and arguing for the merit plan); Joseph A. Colquitt, Rethinking Judicial Nominating Commissions: Independence, Accountability,
} 
councils, an international "best practice" designed to help ensure judicial independence and external accountability. We thus see the emergence of a new orthodoxy-merit selection is good and other methods are retrograde. Because there are few common metrics to evaluate the comparative independence or quality of judiciaries, the new scholarly consensus is largely theoretical, built on anecdotal rather than systematic evidence. $^{4}$

This Article describes the global spread of judicial councils and provides a theory of their formation and features. By our estimate, over sixty percent of countries have some form of judicial council, up from ten percent thirty years ago. ${ }^{5}$ We also provide some evidence as to whether different designs of judicial council affect judicial quality. Although we find that there is little relationship between council adoption and quality, the Article argues that the eternal struggle for a balance between independence and accountability ensures that judicial councils will continue to be a locus of institutional reform. Yet there are limits to the efficacy of institutional solutions to problems of judicial independence. Although councils serve as an arena for contestation for various groups with an interest in judicial performance, they do not by themselves guarantee the substantive outputs of independence and quality.

The Article is organized as follows. First, we discuss the emergence of judicial councils. We then provide a theory of the formation of judicial councils and identify some of the dimensions along which they differ. Next, we test the extent to which different designs of judicial council affect judicial quality. We find that there is little

and Public Support, 34 Fordham URB. LJ. 78 (2007); Mark A. Behrens \& Cary Silverman, The Case for Adopting Appointive Judicial Selection Systems for State Court Judges, 1 CoRnElL J. L. \& PUB. POL'Y 273 (2002) (arguing for appointment over election); Norman L. Greene, A Critical Appraisal of Appointive Selection for State Court Judges: The Judicial Independence Through Fair Appointments Act, 34 FordhAm URB. L.J. 13 (2007) (same); G. Alan Tarr, Designing an Appointive System: The Key Issues, 34 FordhAM URB. L.J. 291 (2007) (same); Jeffery D. Jackson, Beyond Quality: First Principles in Judicial Selection and Their Application to a Commission-Based Selection System, 34 FordHAM URB. L.J. 459 (2007); Steven P. Croley, The Majoritarian Difficulty: Elective Judiciaries and the Rule of Law, 62 U. CHI. L. REV. 689 (1995) (judicial elections undermine rule of law); Paul R. Brace \& Melinda Gann Hall, The Interplay of Preferences, Case Facts, Context, and Rules in the Politics of Judicial Choice, 59 J. POL. 1206 (1997).

${ }^{4}$ But see Stephen J. Choi et al., Judicial Independence, Judicial Quality and the Countermajoritarian Difficulty: An Empirical Test Using Data from State Supreme Courts (2007), available at http://papers.ssrn.com/sol3/papers.cfm?abstract_id=998536 (finding that judges in partisan systems are more productive in terms of number of opinions, but that appointed judges are cited more frequently).

${ }^{5}$ Diffusion data on file with authors. 
relationship between council design and quality. Our theory nevertheless offers a positive explanation for why judicial councils remain attractive institutions. Finally, we conclude with a discussion of the implications of the analysis.

\section{The Tension Between Accountability and Independence}

A long and established literature argues that the ideal of judicial independence is a crucial quality of legal systems, and indeed inherent in the notion of judging. ${ }^{6}$ Naturally, the ideal is not always met, for it remains the case that in every legal system judges are appointed and employed by the state. It would be unusual indeed if judges did not have a role in implementing social policy, broadly conceived. ${ }^{7}$ In democracies, this implies the need for some accountability of judges. While judicial independence is widely studied, ${ }^{8}$ accountability has been the subject of much less inquiry. It requires that the judiciary as a whole maintain some level of responsiveness to society, as well as a high level of professionalism and quality on the part of its members. This section discusses judicial councils as devices to ensure both independence and accountability.

\section{A. Judicial Councils in Civil Law and Common Law Systems}

\footnotetext{
${ }^{6}$ See the recent volume JUDICIAL INDEPENDENCE AT THE CROSSROADS: AN INTERDISCIPLINARY APPROACH (Stephen B. Burbank \& Barry Friedman eds., 2003).

${ }^{7}$ Martin Shapiro, Courts: A Comparative And Political AnAlysis (1981).

8 See, e.g., Sanford Levinson, Identifying "Independence," 86 B.U. L. REV. 1297 (2006) (identifying formal and informal pressure on the judiciary); Stephen B. Burbank, The Architecture of Judicial Independence, 72 S. CAL. L. REV. 315 (1999) (explaining judicial independence in contemporary American history); Archibald Cox, The Independence of Judiciary: History and Purposes, 21 U. DAYTON L. REV. 565 (1996) (discussing historical reasons for judicial independence); John Ferejohn \& Larry Kramer, Independent Judges, Dependent Judiciary: Institutionalizing Judicial Restraint, 77 N.Y.U. L.REV. 962 (2002) (arguing that independence and accountability aim at a well-functioning system of adjudication); John Ferejohn, Judicializing Politics, Politicizing the Law, 65 LAw \& CONT. ProBS. 45 (2002); John Ferejohn, Independent Judges, Dependent Judiciary: Explaining Judicial Independence, 72 S. CAL. L. REV. 353 (1999) (discussing institutional protections for judges and the judiciary and explaining interest theories of judicial independence); Gordon Bermant \& Russell Wheeler, Federal Judges and the Judicial Branch: Their Independence and Accountability, 46 MERCER L. REV. (1995) (identifying different levels of independence, including decisional independence, personal independence, procedural independence, administrative independence; and different levels of accountability, namely internal vs. external accountability); Frank Kahn Zemans, The Accountable Judge: Guardian of Judicial Independence, $72 \mathrm{~S}$. CAL. L. REV. 625-56 (1999) (discussing institutional versus decisional independence); also Burbank \& Friedman, supra note 6.
} 
Judicial councils are bodies that are designed to insulate the functions of appointment, promotion, and discipline of judges from the partisan political process while ensuring some level of accountability. Judicial councils lie somewhere in between the polar extremes of letting judges manage their own affairs and the alternative of complete political control of appointments, promotion, and discipline. The first model of judicial self-management arguably errs too far on the side of independence, while pure political control may make judges too accountable in the sense that they will consider the preferences of their political principals in the course of deciding specific cases. There are a wide variety of models of councils, in which the composition and competences reflect the concern about the judiciary in a specific context, balancing between demands for accountability and independence.

France established the first High Council of the Judiciary (Conseil Superieur de la Magistrature) in 1946. ${ }^{9}$ It was in charge of managing judicial personnel but only a minority of members were themselves magistrates elected directly by fellow judges. ${ }^{10}$ Italy's judicial council (Consiglio Superiore della Magistratura), created in 1958, was the first to fully insulate the entire judiciary from political control, a model that has been followed in other judicial reforms. ${ }^{11}$ Spain $^{12}$ and Portugal ${ }^{13}$ have slightly different

\footnotetext{
${ }^{9}$ A precursor for judicial councils can be seen in the use of formal nominations committees composed of various governmental officials. See, e.g., Constitution of Albania, 1925 (judicial nominations from special committee of judges, prosecutors, and Minister of Justice).

${ }^{10}$ In the Fifth Republic, the President of the Republic took over the appointments of all the members and reinstated most of the traditional powers of the Minister of Justice and higher-ranking judges. The cohabitation period in the 1980s eventually led to another reform (Loi Constitutionnelle of July 1993 and Loi Organique of Feb. 1994). The Council has two committees, one for judges and another one for prosecutors. The Council has a total of sixteen members. Each committee has one administrative judge chosen by the administrative judges (Conseil d'État) and three individuals chosen by the President, the Senate, and the National Assembly each. For the judicial committee, it has also five judges elected by the fellow judges and one prosecutor chosen by the fellow prosecutors; for the prosecutorial committee, it has one judge elected by the fellow judges and five prosecutors for the prosecutorial formation. The President and the Minister of Justice sit ex officio. See Cheryl Thomas, Judicial Appointments in Continental Europe, Lord Chancellor's Department, Research Series 6/97, 1997.

${ }^{11}$ The Italian Council was made up of thirty-three members, twenty magistrates elected directly by the judges, ten lawyers or law professors nominated by the Parliament, and the President, the Chief-Justice, and the Chief-Prosecutor all serving ex officio. It has been reformed recently to include only twenty-four members, sixteen ordinary magistrates and prosecutors and eight lawyers or law professors with fifteen years experience in the legal profession, all of whom are appointed by the Parliament. See Thomas, supra note 10 .
} 
models introduced after the fall of the dictatorships in the mid 1970s, in which judges constitute a significant proportion of the members. These councils have final decisionmaking in all cases of promotion, tenure, and removal. Judicial salaries are also technically within their authority but usually tempered by the department in charge of the budget (typically the Ministry of Finance). The power of high-ranking magistrates has been dramatically reduced in most of these countries (as a consequence of junior-ranking judges being appointed to the judicial council) and strong unions or judicial associations have emerged. ${ }^{14}$

The French and Italian cases were motivated by a concern about excessive politicization and consequently granted extensive independence to the judicial power. After some time, however, courts became more extensively involved in politics and accountability issues came to the fore. For example, in France, reforms in the 1990s were clearly driven by political events that have empowered the judiciary. Although the Fifth Republic maintained the traditional subordination of the French judiciary to the executive and the legislature, and the rather docile judiciary exercised individual and collective judicial self-restraint, conflicts began to develop in the late 1960s and 1970s. ${ }^{15}$ The consolidation of judicial review by the Constitutional Council in the mid-1970s had a major and enduring impact. The sharp increase in litigation, both civil and administrative, the criminalization of many activities, and the extension of the scope of application of the European Convention of Human Rights, all served to increase the

\footnotetext{
${ }^{12}$ The Spanish Council (Consejo General del Poder Judicial) has twenty members, twelve judges and eight lawyers all appointed by the Parliament and the Chief-Justice ex officio. For prosecutors, there is a council made up of twelve prosecutors (Consejo Fiscal).

${ }^{13}$ There are three councils in Portugal, one for judicial courts (Conselho Superior da Magistratura), one for administrative courts (Conselho Superior dos Tribunais Administrativos e Fiscais), and one for prosecutors (Conselho Superior do Ministério Público).

${ }^{14}$ A good summary can be found in Thierry-Serge Renoux, 2000, Les Conseils Supérieurs de la Magistrature en Europe, Documentation Française (Coll. Perspectives sur la justice). About the unionization of the judiciary, see Willem de Haan et al., Radical French Judges: Syndicat de la Magistrature, 16 J.L. \& SOC'Y 477-82 (1989) (explaining the role of the union of judges).

${ }^{15}$ See Michael. H. Davis, A Government of Judges: An Historical Re-View, 35 AM. J. CoMP. L. 559 (1987) (explaining why the American government of judges is disliked by the French legal scholars); John Bell, Principles and Methods of Judicial Selection in France, 61 S. CAL. L. Rev. 1757 (1988); Alec Stone, The Birth Of Judicial Politics In France (1992); Vincent Wright, The Fifth Republic: From the Droit d'Etat to the Etat de Droit?, 22 W. Eur. Pol. 92 (1999), and Dories Marie Provine \& Antoine Garapon, The Selection of Judges in France: Searching for a New Legitimacy, in APPOINTING JUDGES IN AN AGE OF Judicial Power 176 (Kate Malleson \& Peter H. Russell eds., 2006).
} 
influence of the French judiciary. At the same time, several political scandals gave the judiciary an important influence over politics. France, with its tradition of viewing the judiciary as a faceless collectivity dispensing justice, was now faced with a new kind of celebrity. ${ }^{16}$ Though the judiciary as a whole is still quite self-restrained, a number of individual judges gained notoriety because of their role in investigating political scandals. This in turn has led to the introduction of a debate about the lack of external accountability of judges. ${ }^{17}$

The pattern in Italy is similar. The Italian judicial system is notable for its extreme independence, in which the judicial council controls virtually all aspects of judicial appointment and promotion for the ordinary judiciary. ${ }^{18}$ The balance of power on the council is clearly in the hands of the judiciary, and since the internal hierarchy of the judiciary has largely been undermined, all decisions on the status of magistrates are taken by the council. Prominent scandal investigations related to businessmen, politicians, and bureaucrats marked the period from 1992 to 1997, raising questions about judicial accountability. ${ }^{19}$ Consequently, the composition of the council was altered in 2002 to increase the influence of the Parliament.

The French-Italian model has been exported to Latin America and other developing countries. ${ }^{20}$ Indeed, the World Bank and other multilateral donor agencies have made judicial councils part of the standard package of institutions associated with

\footnotetext{
${ }^{16}$ See Doris Marie Provine, Courts in the Political Process in France, in Courts, LAw And PoLITICS IN Comparative Perspective, at 203-04 (Herbert Jacob et al., eds., 1996)..

${ }^{17}$ VAléry Turcey, Le Conseil Superieur de la Magistrature FranÇais: Bilan et Perspectives (2005).

${ }^{18}$ See Thomas, supra note 10.

19 Patrizia Pederzoli, The Reform of the Judiciary in ITALIAN Politics: QuO VADIS 153-71 (Carlo Guarnieri \& James Newell eds., 2004); David Nelken, The Judges and Political Corruption in Italy, in The Corruption of Politics AND the Politics of Corruption 95-112 (Michael Levi \& David Nelken eds., 1996); Carlo Guarnieri, Judicial Independence in Latin Countries in Western Europ, in Judicial IndePendence In The Age of Democracy, Critical Perspectives AROUND THE WORLD (Peter Russell \& David M. O’Brien eds., 2001).

${ }^{20}$ See, e.g., Rebecca Bill Chavez, The Appointment and Removal Process for Judges in Argentina: The Role of Judicial Councils and Impeachment Juries in Promoting Judicial Independence, 49 LATIN AMERICAN POL. \& Soc. 33 (2005) (Argentina). Some refer to a distinction between a "Northern European Model" more focused on management concerns and a "Southern European Model" that is constitutionalized and focusing on structural independence. Wim Voermans \& Pim Albers, Councils for the Judiciary in EU Countries, European Council for the Efficiency of Justice, CEPEJ (2003). We reject this distinction as unhelpful, but rather develop an index of powers and competences discussed infra, section $\mathrm{V}$.
} 
judicial reform and rule of law programming. ${ }^{21}$ Efforts to produce model "best practices" have ensured much replication and refinement of the judicial council model. For example, the Association of European Magistrates for Democracy and Freedom (MEDEL) produced a Draft Additional Protocol to the European Convention on Human Rights, called the Elements of European Statute on the Judiciary (known as the "Palermo Declaration"). This model statute states that there shall be a supreme council of magistracy, at least half of whom are judges and also including appointees of the parliament. ${ }^{22}$ The model statute also declares that the supreme council will produce a budget for the courts, manage the administration, and control recruitment, assignment ${ }^{23}$ and discipline of judges, ${ }^{24}$ thus guaranteeing judicial independence. The Council of Europe made a similar recommendation in a document published in $1994 .^{25}$ Other international organizations have followed suit. ${ }^{26}$

The motivating concern for adoption of councils in the French-Italian tradition was ensuring independence of the judiciary after periods of undemocratic rule. To entrench judicial independence, most of these countries enshrined the judicial council in their constitution. Independence, however, is a complex and multifaceted phenomenon. Even though judges may be independent from political control, they may become dependent on other forces, such as senior judges in a judicial hierarchy—with just as

\footnotetext{
${ }^{21}$ See Linn Hammergren, Do Judicial Councils Further Judicial Reform? Lessons from Latin America (Working-Paper Series Democracy and Rule of Law Project 28, 2002). See also Pedro C. Magalhaes, The Politics of Judicial Reform in Eastern Europe, 32 COMP. PoL. 43-62 (1999) (discussing the judicial institutional design in Bulgaria, Hungary, and Poland and how it relates to the bargaining process between the different political actors); ); Pilar Domingo, Judicial Independence: The Politics of the Supreme Court of Mexico, 32 J. LAT. AMER. STUD. 705 (2000) (arguing that specific constitutional reforms and the politics of co-optation subordinated the judiciary to the dominant party until 1994); Peter H. Solomon, Putin's Judicial Reform: Making Judges Accountable as well as Independent, 11 E. EUR. CONST. REV. 117-23 (2002) (discussing the reforms to the Judicial Qualification Commission); Lauren Castaldi, Judicial Independence Threatened in Venezuela: The Removal of Venezuelan Judges and the Complications of Rule of Law Reform, 37 GEORGETOWn J. INT'L L. 477 (2006) (discussing the current situation in Venezuela).

${ }^{22}$ Art. 3.2.

${ }^{23}$ Art. 3.1.

${ }^{24}$ Subject to review by the Supreme Court. Art. 3.4.

${ }^{25}$ Recommendation No.R (94) 12 of the Committee of Ministers to Member States on the Independence, Efficiency and Role of Judges (1994) (Council of Europe Recommendation), art. I.2.c

${ }^{26}$ Violane Autheman \& Sandra Elena, Global Best Practices-Judicial Councils: Lessons Learned from Europe and Latin America, IFES, 2004 (arguing that judicial councils should be composed of a majority of judges elected by their peers and should be tasked with selection, promotion, discipline, and training).
} 
much potential to distort individual decision-making as more conventional political influence. $^{27}$ In civil law countries, in particular, a large proportion of judges are recruited directly from law school using some form of public examination, with no or limited requirements of previous professional experience. ${ }^{28}$ This model emphasizes socialization within the ranks of the judicial profession and creates the potential for institutional pressures on judges to decide individual cases in ways that are at odds with their own conscience or reading of the law.

Perhaps because of concerns over this structural problem, external accountability has emerged as a second goal of councils. This is exemplified by the judicial councils in some civil law countries, such as Germany, Austria, and the Netherlands, that enjoy fewer competences than do those in the French-Italian model. These councils are limited to playing a role in selection (rather than promotion or discipline) of judges, or are heavily influenced by regional and federal governments. The political impact of these councils on the judiciary has been less clear than in the four European countries utilizing the French-Italian model. ${ }^{29}$

Consider the Dutch case. Important reforms were recently introduced to ensure more transparency and accountability but were not due to high profile political scandals. The Dutch judiciary was historically very restrained, with a tradition of deference and a strong concept of parliamentary sovereignty. The 1956 constitutional reform, designed to accommodate the nascent European legal order, paved the way for more judicial activism and judges gradually became more active in enforcing the European Convention of Human Rights. ${ }^{30}$ In 2002, a Council for the Judiciary (Raad voor de Rechtspraak) was created to take primary responsibility for the organization and financing of the Dutch

\footnotetext{
${ }^{27}$ See Owen Fiss, The Right Degree of Independence, in TRANSITIONS TO DEMOCRACY IN LATIN AMERICA: THE Role OF THE JUdiCIARY 55-72 (Irwin Stotzky ed., 1993) (focusing on independence within the judicial hierarchy).

${ }^{28}$ Nicholas L. Georgakopoulos, Discretion in the Career and Recognition Judiciary, 7 CHI L. SCH. ROUNDTABLE 205 (2000).

${ }^{29}$ See Thomas, supra note 10.

${ }^{30}$ See Thijman Koopmans, Courts And Political Institutions, 76-84 (2003) (describing the growth of power of the Dutch judiciary).
} 
Judiciary. ${ }^{31}$ The primary impetus for reforms has not been the judicialization of politics but rather a perceived need for more accountability and better allocation of resources.

The councils in civil law jurisdictions vary in their relationship with the Supreme Court. In some countries, such as Costa Rica and Austria, the judicial council is a subordinate organ of the Supreme Court tasked with judicial management. ${ }^{32}$ In other countries, judicial councils are independent bodies with constitutional status. Further, in some countries councils govern the entire judiciary, while in others they only govern lower courts. ${ }^{33}$

The case of Brazil is of special interest in this context. The Brazilian judiciary has traditionally been considerably decentralized, very much influenced by the United States model. ${ }^{34}$ Although there are serious administrative and financial advantages of decentralization, it has also created serious drawbacks in terms of effective disciplinary action and accountability. Brazil's first judicial council was created in 1977. The primary function of the council was disciplinary and it had no budgetary or administrative functions. Though formally designed to provide the appearance of independence, the 1977 version of the judicial council did little to constrain potential military interference with the courts. Indeed, judicial independence was in one sense greatest between 1988 and 2004, when judges enjoyed a vastly expanded domain of governance but had little oversight. The association between the council and the dictatorship was the likely reason for its abolition in 1988 with the return to democracy. Nevertheless, in 2004, Brazil passed a constitutional amendment to introduce a new judicial council with a very different structure from its predecessor. ${ }^{35}$ Only with the recent reforms is there a promise

\footnotetext{
${ }^{31}$ The creation of the Council for the Judiciary followed the Leemhuis Commission's advice to the Minister of Justice by the report "Updating the Administration of Justice", in 1998.

${ }^{32}$ The 1977 Brazilian council (Conselho Nacional da Magistratura) was another good example. However, the 2004 council (Conselho Nacional de Justiça) has nine judges from different courts, including the ChiefJustice ex officio, two prosecutors, two lawyers (representatives of the bar association) and two laymen appointed by the Senate and the House respectively.

${ }^{33}$ Voermans \& Albers, supra note 20, provide the examples of Guatemala and Argentina.

${ }^{34}$ See the discussion by Maria Angela Oliveira, Reforming the Brazilian Supreme Federal Court: A Comparative Approach, 5 Wash. U. Global StUdies L. Rev. 99 (2006).

${ }^{35}$ The new model includes nine judges, two prosecutors, two lawyers, and two laymen appointed by the legislature.
} 
of a strong but politically accountable judiciary. It remains, of course, to be seen whether this materializes.

Recruitment of the judiciary in common law countries has traditionally drawn from more senior lawyers who have a wider range of previous experience and socialization than do judges in the civil law jurisdictions. ${ }^{36}$ Therefore, external accountability has been a major motivating factor in shaping the design of judicial appointment systems. Compared to the civil law judiciaries, common law judges have relatively few opportunities for advancement, and hence there is less capacity for political authorities to use the promise of higher office to influence judicial decision-making. ${ }^{37}$ Accordingly, appointments processes have received serious attention since judges are fairly immune from pressures once appointed. In the United Kingdom, the Constitutional Reform Act 2005 has created the Judicial Appointments Commission responsible for appointments based solely on merit. ${ }^{38}$ There is nevertheless a good deal of discussion as to how to balance the merit principle with other functionalist goals such as affirmative action and the Commission is anticipated to be able to produce a judiciary that is both higher quality and more diverse. ${ }^{39}$ The advantages of a Judicial Appointment

\footnotetext{
${ }^{36}$ See Georgakopoulos, supra note 28. Debate in common law countries tends to focus on the merits of the appointees and diversity concerns. See, e.g., Kate Malleson, Selecting Judges in the Era of Devolution and Human Rights, in Building the UK's New Supreme Court, in NATIONAL AND COMPARATIVE PerSPECtiveS (Andrew Le Sueur ed., 2004).

${ }^{37}$ C $f$ J. Mark Ramseyer \& ERIC Rasmusen, Measuring Judicial Independence (2004) (documenting political manipulation of judicial career structures in Japan). However, see David M. O'Brien \& Yasou Ohkoshi, Shifting Judicial Independence from Within: The Japanese Judiciary, in , JUDICIAL Independence in the Age of Democracy, Critical Perspectives around the World (Peter Russell \& David M. O’Brien eds., 2001) (arguing that Ramseyer and Rasmusen have misunderstood the manipulation of the judiciary in Japan as political by the LDP when it is merely bureaucratic by the faceless General Secretariat of the Supreme Court).

${ }^{38}$ The composition of the JAC is fifteen, seven are judges and magistrates, two lawyers (one barrister and one solicitor), and six are laymen (including the chairman). It started selecting judges in Apr. 2006. KATE MALLESON, THE LEGAL SYSTEM ch. 17.40 (2005), argues that the JAC is effectively dominated by the judiciary. The fact that the council is chaired by a non-lawyer does not seem to counter a strong judicial membership. The traditional role of the Lord Chancellor in judicial appointments has been the object of study by Anthony Bradney, The Judicial Activity of the Lord Chancellor 1946-1987: A Pellet, 16 J.L. \& SOC'Y 360 (1989).

${ }^{39}$ For a discussion on the extent to which merit selection is consistent with affirmative action in the judiciary, see Kate Malleson, Rethinking the Merit Principle in Judicial Selection, 33 J.L. \& SoC'y 126-40 (2006); see also Kathleen A. Bratton \& Rorie L. Spill, Existing Diversity and Judicial Selection: The Role of Appointment Method in Establishing Gender Diversity in State Supreme Courts, 83 Social SCIENCE QUARTERLY 504 (2002) (presenting empirical evidence that appointed systems of judicial selection produce more diversity than election systems). The Canadian experience of provincial and federal advisory committees has been appraised as a good model to promote women and minorities within the judiciary.
} 
Commission have also been at the heart of the debate in New Zealand and in Australia, where judicial appointments are still in the competence of the Attorney-General. Currently, judicial appointment protocols have been developed to enhance independence and external accountability (by including mandatory consultation with several office holders). ${ }^{40}$

Within the common law world, the case of Singapore is also an interesting one that illustrates the dangers of assuming that judicial involvement in appointments ensures complete independence. There is a Legal Service Commission in Singapore, but its role is somewhat limited. ${ }^{41}$ The president appoints judges of the Supreme Court on the recommendation of the prime minister after consultation with the Chief Justice. The Legal Service Commission supervises and assigns the placement of the subordinate court judges and magistrates who have the status of civil servants; however, the president appoints subordinate court judges on the recommendation of the Chief Justice. ${ }^{42}$ The Chief Justice in Singapore is probably the most well-paid judge in the world, with a salary of well over one million U.S. dollars, and the judiciary is widely praised for its quality and independence. Nevertheless, it is also known for its docility in cases of great importance to the ruling party. One might characterize this situation as being one in which the bribes are legalized in the form of salaries, and in which the person of the

There are wide different models in Canada, but usually judges are not a majority in the council. The federal committee has seven members, three laymen, three lawyers, and one judge. See Kate Malleson, The Use of Judicial Appointment Commissions: A Review of the US and Canadian Models, Lord Chancellor's Department, Research Series 6/97, 1997.

${ }^{40}$ Empirical analysis is provided by Mita Bhattacharya \& Russell Smyth, 30 The Determinants of Judicial Prestige and Influence: Some Empirical Evidence from the High Court of Australia, J. LEGAL STUD. 22352 (2001) and Pushkar Maitra \& Russell Smyth, Judicial Independence, Judicial Promotion and the Enforcement of Legislative Wealth Transfers - An Empirical Study of the New Zealand High Court, EuR. J.L. \& ECON., at 17 (2004). See also discussion by John M Williams, Judicial Independence in Australia, in Judicial independence in the Age of Democracy, Critical Perspectives Around the World ( Peter Russell \& David M. O'Brien eds., 2001) (showing that while the structural guarantees are quite robust and few attempts have made to remove judges, there are serious proposals for reform).

${ }^{41}$ See Kim Teck Kim Seah, The Origins and Present Constitutional Position of Singapore's Legal Service Commission, SING. ACAD. L.J., at 2 (1990).

${ }^{42}$ The judicial branch of the Legal Service Commission is headed by the Registrar of the Supreme Court but the ultimate responsibility for managing lies with the Chief Justice. 
Chief Justice operates to ensure that lower judges do not stray from the formula of independence in commercial cases but docility in political ones. ${ }^{43}$

\section{B. The American Experience}

In many American states, concern over traditional methods of judicial selection (either appointment by politicians or direct election by the public) led to the adoption of "Merit Commissions" to remove partisan politics from judicial appointments and base selection on merit. Merit Commissions can be seen as analogous to judicial councils, though their scope of activity is more limited. Because in common law systems, the judiciary is not a "career judiciary" in the civil law sense, there is less interest in having independent commissions handle discipline, promotions, and reassignments, and greater emphasis on initial appointments. The basic institutional design, however-namely setting up non-partisan mixed bodies to screen and select judicial candidates - is similar to the judicial commission.

Sometimes called the "Missouri Plan" (although some assert that it was first adopted in California) or "Merit Plan," this system features a non-partisan judicial selection commission composed of judges, lawyers, and political appointees. ${ }^{44}$ The inspiration for this institution was a famous 1906 speech by Roscoe Pound and can be seen as consistent with early twentieth century view in the value of technocracy and administrative insulation from politics. ${ }^{45}$ The Merit Commission is responsible for nominating judges, exclusively in some states and in other states sending a set of candidates from which the Governor chooses appointees. Merit Plan judges are typically subject to uncontested retention elections but judges rarely lose these elections. ${ }^{46}$ As of

\footnotetext{
${ }^{43}$ Gordon Silverstein, Singapore: The Exception that Proves Rules Matter, in RULE By LAW: THE Politics OF COURTS IN AUTHORITARIAN Regimes (Tom Ginsburg \& Tamir Moustafa eds., 2008).

${ }^{44}$ In Missouri, the Commission has seven members: the Chief Justice, three lawyers elected by the bar from different appellate districts, and three laypersons appointed by the Governor. For an analysis, see Hanssen, supra note 1.

${ }^{45}$ Roscoe Pound, The Causes of Popular Dissatisfaction With the Administration of Justice, 20 J. AM. JuD. SOC'Y 178 (1937).

${ }^{46}$ Peter Webster, Selection and Retention of Judges: Is There one Best Method?, 23 FLA. ST. U. L. REV. 1 (1995); Reddick, supra note 3, at 10 (noting only thirty-three judges lost retention elections in the entire United States between 1942 and 1978).
} 
1990, twenty-three states used the Merit Plan for initial appointment. Most states adopted these institutions in the 1960 s and 1970s. ${ }^{47}$

A general assumption in the literature is that Merit Plan systems will expand independence. $^{48}$ For example, Hanssen tests the effect of partisan division on appointment and retention systems, assuming that Merit Plan correlates with independence. ${ }^{49}$ He finds that, broadly speaking, states using merit plans tend to correlate with higher levels of political competition (and hence presumed demand for judicial independence) than those using partisan elections. ${ }^{50}$ Hanssen also finds that states switch to merit plans when they have increased party competition and policy differences between parties. This is consistent with literature that emphasizes the role of partisan competition in incentivizing judicial independence. ${ }^{51}$

Nevertheless, we know of no study that has demonstrated an actual improvement in judicial independence or quality after adoption of the Merit Plan, and the actual impact on quality is debatable. ${ }^{52}$ In a comprehensive review of the social scientific literature, Reddick concludes that there is little support for "proponents' claims that merit selection insulates judicial selection from political forces, makes judges accountable to the public, and identifies judges who are substantially different from judges chosen through other systems." 53 However, as Hanssen put it "(t)here is today a strong consensus that, of all

\footnotetext{
${ }^{47}$ F. Andrew Hannsen, Learning About Judicial Independence: Institutional Change in State Courts, 33 J. LEGAL STUD. 431-62 (2004). residual category of "other" appointment methods (such as legislative or gubernatorial appointment. $I d$. at 720 ("In 95 percent of partisan election states the same party controlled both houses of the legislature, versus in 87 percent of merit plan states and 81 percent of other states").

${ }^{51}$ J. Mark Ramseyer, The Puzzling (In)Dependence of Courts, 23 J. LEg. STUD. 721 (1994); see also Tom Ginsburg, Judicial Review In New Democracies (2003); Mathew Stephenson, When the Devil Turns ... The Political Foundations of Independent Judicial Review 32 J. LEG. STUD. 59 (2003); Lee Epstein et al., Selecting Selection Systems, in JudiCIAL InDEPENDENCE AT THE CROSSROADS: AN INTERDISCIPLINARY APPROACH 191-226 (Stephen B. Burbank \& Barry Friedman, eds., 2002).

${ }^{52}$ Webster, supra note 46; Henry Glick, The Promise and Performance of the Missouri Plan: Judicial Selection in the Fifty States, 32 U. Miami L. Rev. 519 (1978). See further discussion in Choi et al., supra note 4.

${ }^{53}$ Reddick, supra note 3, at 15 of manuscript.
} 
the procedures, the merit plan best insulates the state judiciary from partisan political pressure." 54

The nominating commission under the Merit Plan is essentially a judicial council by another name, with its function limited to selection of judges. As a common law country with judges that tend to be appointed relatively late in life, the United States has little need for independent bodies to engage in promotion of judges. Thus the commissions play a relatively limited role, but focus on the crucial locus of partisan pressure. This illustrates the importance of understanding institutional variation in conditioning demand for the judicial council model.

\section{The British Experience}

The British case is of particular significance given its recent reforms to a venerable system. In 2003, Prime Minister Blair's Government announced its intention to modify the system for judicial appointments in England and Wales. The reform was justified as advancing the twin goals of improving judicial independence and enhancing accountability and public confidence. Although the independence of the judiciary was confirmed in the Act of Settlement 1701, and since then strong norms of judicial immunity have made it quite difficult to remove judges, appointments remained in the hands of the Lord Chancellor, a senior government official. ${ }^{55}$ The traditional view was that the Lord Chancellor was the judiciary's representative in the government and the government's representative to the judiciary, hence a unique office well placed to represent the view of each side. ${ }^{56}$ The English judiciary was never perceived to be a separate branch of government in the American sense. ${ }^{57}$ Furthermore, a system

\footnotetext{
${ }^{54}$ Hanssen, supra note 47 , at 452.

55 For example, Stevens mentions several important episodes of political interference with the judiciary (including the right of the Crown not to reappoint judges on the change of a monarch) but notes the declining role of the judiciary until the 1960s. He argues that the development of high formalism that protected the English judiciary from possible political interference made the judiciary increasingly irrelevant. See Robert Stevens, The English Judges: Their Role In The Changing Constitution (2005), chs. 1 and 2. See also the recent volume BuILDING THE UK's SUPREME COURT: NATIONAL AND Comparative PersPectives (Andrew Le Seur ed., 2004)

${ }^{56}$ See J. Steyn, The Case for a Supreme Court, 118 L. Q. R. 382 (contesting this view and emphasizing that in practice the Lord Chancellor delegates to the Law Lords judicial business).

${ }^{57}$ See J.A.G. Griffith, The Politics OF The Judiciary (5th ed, 1999), at chs. 8 and 9, where he argues that the myth of neutrality has undermined the building-up of a strong judiciary. The author defends a
} 
dependent on the Lord Chancellor created a unified and hierarchical judiciary. This structure did not promote diversity of opinions since someone who did not conform to the views of the establishment was not likely to be chosen by the Lord Chancellor for a judicial post.

The increasing profile of the English judiciary in recent years has led to pressures for more judicial accountability. The Pinochet case in 1999 raised serious questions about having the most senior judiciary sitting at the House of Lords. ${ }^{58}$ There have been conflicts over sentencing in the aftermath of the Human Rights Act 1998. Finally, the case of McGonnell v. UK (2000) in the European Court of Human Rights concerning the office of bailiff of the island of Guernsey had an important impact. ${ }^{59}$ In that case, the Court decided that a single official who serves as both a judge and in an administrative role violates Article 6 of the European Convention of Human Rights (although in practice, in England and Wales, the Lord Chancellor has traditionally avoided sitting on cases where there might be a conflict of interest). Another source of pressure for more accountability has been the growth of judicial review and the perception that judicial interference has increased significantly. ${ }^{60}$

One important concern is the lack of minorities and women in the bench, thus providing a sense of gender and racial bias in the appointments mechanism. Some have expressed concern that a small clique from Oxford and Cambridge dominates the appointments. ${ }^{61}$ Furthermore, there have been indications of personal and corporate bias

political role of the judiciary in areas such as law and order or social issues. See also Stevens, supra note 55, at chs. 6 and 7, and Robert J. Martineau, Appellate Justice In ENGLAND AND the United States: A COMPARATIVE APPROACH (1990).

${ }^{58}$ The contradictory decisions taken by different panels of three Law Lords were not easily understood by the public. For a detailed account, see Stevens, supra note 55, at ch. 8.

${ }^{59}$ McGonnell v. UK (2000) 30 EHRR 289.

${ }^{60}$ See, among others, Robert Stevens, A Loss of Innocence? Judicial Independence and the Separation of Powers, 19 OXFoRD J. LEG. STUD. 365 (1999) and Matthew Flinders, Mechanisms of Judicial Accountability in British Central Government, 54 PARLIAMENTARY AfFAIRS 54 (2001).

${ }^{61}$ For an empirical analysis, see Jordi Blanes \& Clare Leaver, An Economic Analysis of Judicial Diversity Part I: Judicial Promotions, Oxford University mimeograph (2007). See also Griffith, supra note 57, at 18-21 and Herbert M. Kritzer, Courts, Justice and Politics in England, in COURTS, LAW AND Politics IN Comparative Perspective 91, at 92 (Herbert Jacob et al. eds., 1996). 
in judicial profiles. ${ }^{62}$ The demands for more diversity in the judiciary called for a new method of judicial selection.

In 2003, Prime Minister Blair's Government announced its intention to change the system for making appointments to the judiciary in England and Wales. ${ }^{63}$ The Constitutional Reform Act 2005 introduced several substantive changes in England and Wales, including a statutory duty on government members not to influence judicial decisions. The most far-reaching reforms were the abolishment of the Lord Chancellor with the transfer of his judicial functions (as the most senior judge in England and Wales) to the President of the Courts of England and Wales (formerly known as Lord Chief Justice of England and Wales) ${ }^{64}$ and the creation of a new Supreme Court, with twelve judges independent of and removed from the House of Lords with their own independent appointment system. ${ }^{65}$ And crucially, a Judicial Appointments Commission was created, responsible for recommending candidates for judicial appointments on a more transparent basis and based solely on merit.

\section{Balancing Independence and Accountability}

This brief survey illustrates that it is clearly impossible to eliminate political pressure on the judiciary. While adequate institutions might enhance judicial independence and minimize the problems of a politicized judiciary, increasing the powers and independence enjoyed by judges risks creating the opposite problem of over-

\footnotetext{
${ }^{62}$ See GrifFITH, supra note 57, at chs. 3 to 6.

${ }^{63}$ In the case of Scotland, judicial appointments were under review since Sept. 1999 and an independent Judicial Appointments Board was established in June 2002.

${ }^{64}$ The President of the Courts of England and Wales sits in the Court of Appeal, the High Court and the Crown Court, among others, is responsible for expressing the views of the judiciary and for welfare, training, and guidance of the English judiciary. He is not the President of the Supreme Court.

${ }^{65}$ The new Supreme Court is to be launched in 2008 with the current twelve Law Lords (the Lords of Appeal in Ordinary). There will be a Supreme Court ad hoc selection committee presided by the President of the Supreme Court for future appointments. The remaining Lords of Appeal who are members of the House of Lords and eligible to hear and decide judicial business under the Appellate Jurisdiction Act 1876 will not be moved to the Supreme Court (in Jan. 2007, there were thirteen including three former Lord Chancellors).
} 
judicializing public policy. ${ }^{66}$ It is our view that the periodic reforms of judicial appointments and management that we observe within and across countries reflect a dialectic tension between the need to de-politicize the judiciary and the trend toward judicializing politics. Independence is needed to provide the benefits of judicial decisionmaking; once given independence, judges are useful for resolving a wider range of more important disputes; but as more and more tasks are given to the judiciary, there is pressure for greater accountability because the judiciary takes over more functions from democratic processes.

Figure 1 presents a stylized summary of the recurrent calibration between independence and external accountability, synthesizing the different experiences discussed above. Begin in the upper right corner, a judiciary that has little independence or influence. When judges carry little weight over public policy and politics, concerns over independence tend to dominate and reformers may push for a move from a politically dependent weak judiciary to a strong self-regulated judiciary (e.g., the FrenchItalian experience in the 1950s, or Spain and Portugal in the 1970s). This shift gives rise to a judiciary that has some control over its own affairs. Frequently, though not inevitably, judges use this independence to increase their influence over public policy (perhaps as a result of exogenous events). This is represented by a shift to the lower left corner of Figure 1. However, once politics is judicialized in a significant way, pressures arise for greater political accountability. The judiciary remains strong but is more subject to oversight and control. As accountability becomes directed only to a small group of principals and assaults on judicial independence are too successful, we may in some circumstances observe a move from a politically accountable strong judiciary back to politically dependent weak judiciary, as in a rising authoritarian regime. This dynamic framework provides a tool for understanding the various institutional adjustments observed in different countries.

Note that we are not asserting that movement across the various zones of the figure is inevitable. Institutional configurations can be stable for long periods of time,

\footnotetext{
${ }^{66}$ Stephen Burbank, Judicial Independence, Judicial Accountability and Interbranch Relations (U. Pa. L. Sch., Working Paper No. 102, 2006), available at http://sr.nellco.org/upenn/wps/papers/102 (arguing that judicial independence in the United States is at a tipping point because of a characterization of judicial politics as ordinary politics).
} 
and there is no necessary condition that judiciaries shift their location in the figure. What we believe the figure does capture, however, is the potential for cycling among different models of judicial governance and the nature of the pressures that judiciaries will face in particular configurations. We return to these dynamics later in this Article. 
FIGURE 1

CONTROLLING THE JUDICIARY

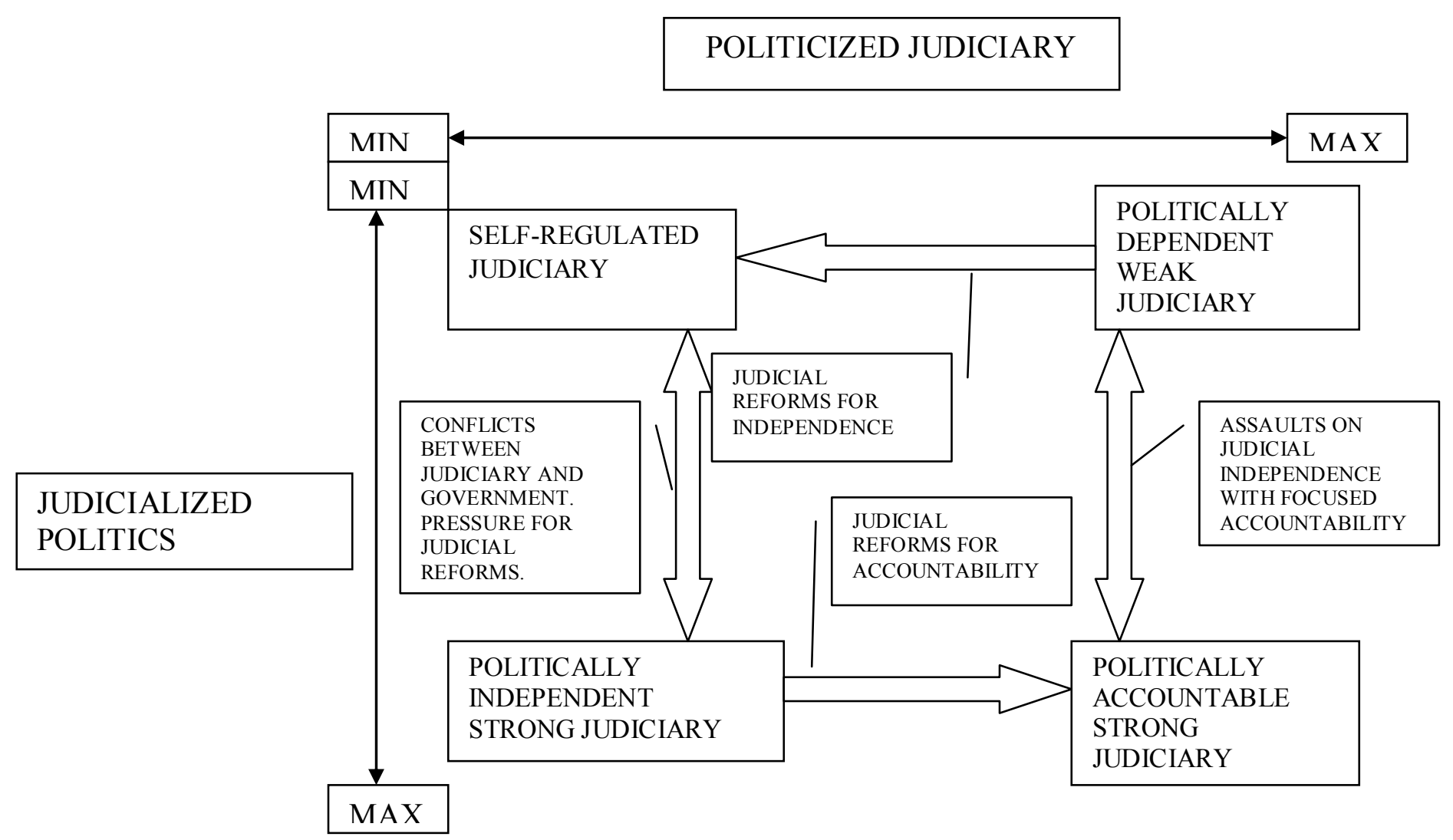




\section{What do Councils Do?}

\section{A. Competences}

Academic work on judicial councils has been so far quite limited. There are very few empirical studies ${ }^{67}$ and there has been no economic or statistical analysis to date that we know of. We have observed that judicial councils operate in very different legal environments and, therefore, we need to understand the particularities before we can compare the role and the powers of judicial councils across countries.

Broadly speaking, judicial councils have three important competences:

(i) Housekeeping functions (managing budget, material resources, operations);

(ii) Appointment of judges; and

(iii) Performance evaluation (promotion, discipline, removal and retention of judges, and judicial salaries).

For all of these functions, the key factor is effective calibration between judicial independence and external accountability. This calibration will be achieved, for example, by the composition or membership of the council, by the appointment mechanism, or by sharing certain functions with other branches of the government or other bodies (even the public in the case of elected judges). We do not assert that there is a universally optimal balance between independence and accountability, but understand that there is a limit to how far one can move in either direction within democracies. ${ }^{68}$ Moving too far in either direction may trigger pressures for a shift as idealized in Figure 1.

Whereas the first competence, housekeeping, is purely managerial, the second and third competences are related to career incentives and more directly contribute to judicial quality. Housekeeping functions deal with practical questions concerning the organization and the running of the judiciary. ${ }^{69}$ These functions can, of course,

\footnotetext{
${ }^{67}$ But see Hammergren, supra note 21.

${ }^{68}$ Hanssen, supra note 1.

${ }^{69}$ We believe the primary rationale to be considered in assigning the task to a council is economies of scale and specialization vis-a-vis alternative managers, such as the Ministry of Justice (arguably better able to do things like purchasing supplies etc.) or the Supreme Court (a body that typically has little time or expertise for management).
} 
potentially affect judicial independence-for example, if material incentives are used to reward certain types of judges. Obviously managerial competences are also important for the efficiency of courts and, in that respect, shape the quality of the legal system. Nevertheless, the other two competences (appointment and performance evaluation) are more directly related to judicial career incentives. If institutions matter for judicial quality, they matter because of their impact on judicial incentives.

\section{B. Composition}

Councils also vary in composition. The council is composed of three possible types of members, (i) judges, (ii) members of other government bodies or their appointees, and (iii) lawyers. Judges on the Council are typically appointed by the Supreme Court or by other courts, while lawyers are appointed by the law society/bar association. Members of government bodies are typically appointed by their organizations.

A general assumption in the literature is that a judicial majority on the council will ensure independence. However, even when the judges are not a numerical majority in the council, they might have a dominant or preponderant role for three reasons. First, most members of a judicial council must rely on information provided by the judiciary itself. Second, a judicial council does not exert direct control over the judiciary (which would hurt the independence of judiciary) but exercises a configuration of powers that mix authority and accountability. This configuration is usually complex and full of

uncertainties that usually call for expertise by judges. Third, judges may have particularly strong incentives to represent judicial interests on the council: after their service on the council, judges will return to their professional careers inside the judiciary whereas the non-judges will go back to their careers outside of the judiciary, which may or may not have any relationship with judicial management issues.

\section{The Interaction of Competence and Composition}

We are particularly interested in whether composition correlates with powers. One hypothesis is that judges will resist external regulation and control. Therefore if non-judges are the majority on the council, we might observe that the Council is given 
less substantive powers, but when judges are the majority, powers are high. A competing hypothesis is that judicial councils (a relatively late historical development) have been set up to control judges and ensure accountability. If this were the case, we should see the percent of judges on the council negatively correlated with the extent of powers. ${ }^{70}$

We can frame this as the question of whether judicial councils are set up to ensure independence of judges from the principals or accountability to the principals (see Figure 1). If judges are a majority on the council, the assumption is that judges utilize the council to exercise self-government and maintain independence. If judges are a minority on the council, the assumption is that the council is a device to constrain the judges and render them more accountable. These two types of councils reflect quite different goals. $^{71}$

To summarize, judicial councils will vary in terms of their competencies and their structures. Interacting competences with composition, we can imagine different configurations. We view extensive competence of a judicial council as enhancing judicial accountability. We follow the conventional wisdom that assumes that judicial majorities on the judicial council promote independence. Interacting these two dimensions, we can see that there are several possible configurations (see Figure 2). Extensive competences create strong councils whereas those limited to housekeeping functions are considered weak councils. Judicial dominance of the council means that they are less likely to be politicized. Nevertheless, the shape of the council will depend on whether or not the judges in the council behave as a homogeneous body. That is easily achieved when judges come from superior courts since these judges will tend to reinforce the judicial hierarchy. If the judges come from various different courts, there may be intra-judicial politics that prevent the judiciary from acting in unified fashion: we may sometime observe the emergence of judicial associations or unions that provide a solution to collective action problems.

\footnotetext{
${ }^{70}$ On the other hand, the politics of setting up the councils may vary greatly depending on local circumstances, in particular the historical balance of power between government and Supreme Court. For example, the extent to which the justices are easily captured by the government will result in different models of judicial council.

${ }^{71}$ Hanssen's data from the United States suggests that the timing of the adoption of council-type mechanisms reflects these motivations.
} 
Figure 2 displays the various models, along with some examples of their operation. 
FIGURE 2

COMPETENCE AND COMPOSITION: TYPOLOGY OF JUDICIAL COUNCILS

COMPOSITION

\begin{tabular}{||c|c|c|c||}
\hline \multirow{2}{*}{ COMPETENCES } & JUDGES FROM & JUDGES FROM & NON-JUDGES \\
& SUPREME & LOWER & DOMINATE \\
& COURT & COURTS & \\
DOMINATE & DOMINATE & \\
EXTENSIVE & STRONG & STRONG NON- & POLITICIZED \\
(DISCIPLINE, & HIERARCHICAL & HIERARCHICAL & JUDICIAL \\
REMOVAL, & JUDICIAL COUNCIL & JUDICIAL COUNCIL & COUNCIL \\
(JAPAN, MEXICO, & (ITALY, FRANCE) & (ECUADOR, \\
PROMOTION, & THAILAND) & & BARBADOS, \\
APPOINTMENTS) & & & SINGAPORE) \\
\hline INTERMEDIATE & HIERARCHICAL & NON- & JUDICIAL \\
(APPOINTMENTS & SELF-REGULATING & HIERARCHICAL & APPOINTMENTS \\
ONLY) & JUDICIAL & SELF-REGULATING & COMMISSION \\
& APPOINTMENTS & JUDICIAL & (USA, UK, \\
& COMMISION & APPOINTMENTS & CANADA, \\
& (BANGLADESH) & COMMISSION & NETHERLANDS, \\
& & (BELGIUM) & GERMANY) \\
\hline MINIMAL & WEAK JUDICIAL & WEAK JUDICIAL & WEAK JUDICIAL \\
(HOUSEKEEPING & COUNCIL & COUNCIL & COUNCIL \\
FUNCTIONS) & (PANAMA) & (BRAZIL, & (PARAGUAY) \\
\hline \hline
\end{tabular}

This discussion suggests that councils are not all of a same type. Local institutional problems, represented by the location in Figure 1, will produce pressures for different types of councils in different circumstances. Even within a country, we may see variation over time as different institutional problems arise.

\section{Empirical Data on Councils}


We have developed a small database on Judicial Councils (see Appendix). The sample consists of the councils in 121 different nation-states. Data was gathered for the most recent iteration of the judicial council available. For ninety-three countries, the Judicial Council is mentioned and described in the country's constitution, so we gathered our information from there. ${ }^{72}$ For twenty-eight other countries, the Judicial Council is not mentioned in the Constitution, or it provides no detail on the composition and powers of the Judicial Council. In these countries, the Judicial Council is left to ordinary law. We gathered data on these countries from an array of sources, including the 2002 study of Hammergren $^{73}$ and a number of country-specific sources. Figures $3 \mathrm{a}$ and $3 \mathrm{~b}$ provide some indication of the trends over time and space.

\section{FIGURE 3a: CONSTITUTIONALIZED JUDICIAL COMMISSIONS OVER TIME}

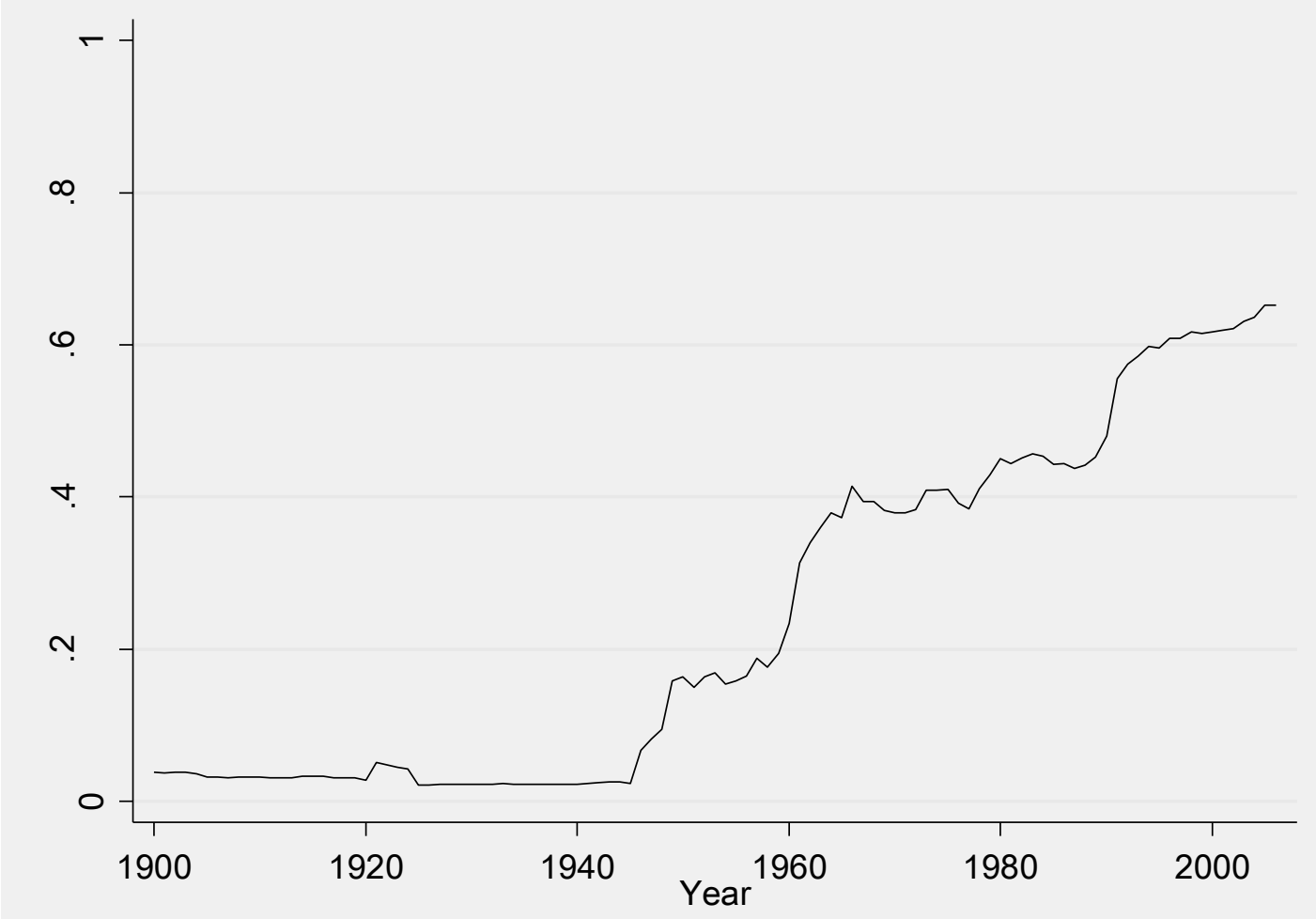

\footnotetext{
${ }^{72}$ This data is from the Comparative Constitutions Project at the University of Illinois; available at www.comparativeconstitutionsproject.org

${ }^{73}$ Hammergren, supra note 21.
} 
FIGURE 3b: CONSTITUTIONALIZED JUDICIAL COMMISSIONS BY REGION IN 2000

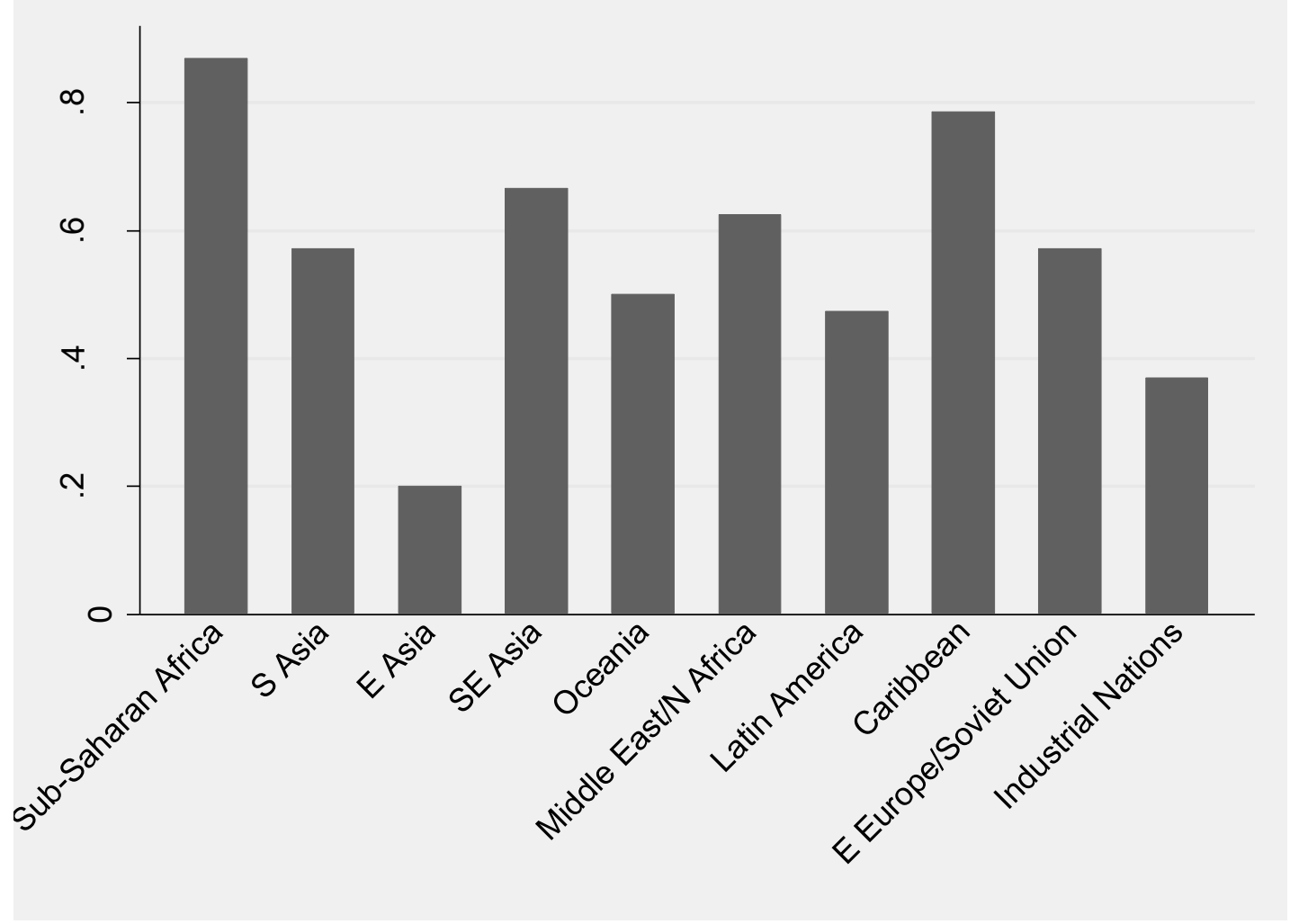

Source: University of Illinois Comparative Constitutions Project, www.comparativeconstitutionsproject.org

Note that the issue of whether or not a council is constitutionalized is itself interesting. If the composition and powers of the council are left to ordinary law, they are subject to enhanced manipulation by the government and other actors and hence less of a guarantee of independence. Presumably those councils lean more toward the accountability pole than the independence pole. Conversely, when the council structure is entrenched in the constitution, it is beyond the reach of ordinary politics and hence likely to reflect a desire for greater levels of judicial independence and insulation. In the results that follow, we predict and find systematically lower independence scores for countries with non-constitutionalized councils. ${ }^{74}$

\footnotetext{
${ }^{74}$ Judicial independence on every measure is lower for these countries. Countries with constitutionalized judicial councils have a mean De Facto Independence (Voigt) score of .51, while those with nonconstitutionalized councils have score .41 , though the $\mathrm{n}$ is too low to determine a significant difference in means. Using Howard and Carey's measure of judicial independence, the means are .47 and .16 respectively, significant at the .01 level.
} 
First, we developed a simple ordinal index of powers/competences ("Power Index"). Each judicial council was rated depending on the extent of its competences. A council that had purely administrative or housekeeping functions council was coded as 1 ; a council with a role in appointment, transfer, and discipline of judges was rated a 3. The intermediate rating of 2 was given to councils that had a limited role either because they could appoint but not discipline judges, or their role was limited in performance-relevant variables. For example, a council that only had a role in recommending judges for appointment or minimal role in discipline would be rated a 2 . We also include information on countries without judicial councils, an important control group. These are denoted by power index 0 . A complete coding of countries with judicial councils is in the Appendix.

Our first prediction was that competences would vary systematically depending on the institutional problem that is faced. Extensive competences correlate with stronger councils. Stronger councils, however, can reflect demands for strong political control and accountability - or judicial self-regulation effectuated by capture of the council. Sorting out which motivation exists in particular contexts is difficult. To evaluate this issue, we use the working assumption that a majority of judges on the council indicates a greater degree of judicial self-regulation.

\section{A. Power of Judges and Institutional Structure}

When judges have extensive powers, judicialization of public policy is likely to follow. In such environments the judicial council may reflect demands for control and accountability. We expect this will be more likely in common law countries as well as any country in which ordinary judges can engage in the power of judicial review. By contrast, where judicial review is limited to a specially designated constitutional court, we do not expect to observe the same level of demand for accountability of the ordinary judiciary, of the type associated with judicial councils. This is because the major issues of social policy will more likely be constitutionalized, so the constitutional court will insulate the ordinary judiciary from politicization, to some degree.

We find only partial support for these conjectures in the descriptive data. Where judicial review is conducted by ordinary courts, competences are less likely to be 
extensive. In general, common law judicial councils are more likely to have extensive powers, not less.

On the other hand, both common law systems and those in which ordinary courts have the power of judicial review are less likely to have a majority of judges on the council, indicating some desire for external control of judges. (Note that the last column ofFigure 4 is based on a smaller sample of countries because data on Council composition was unavailable for some systems.)

\section{FIGURE 4:}

\section{JUDICIAL POWERS, COUNCIL COMPETENCE AND COMPOSITION}

\begin{tabular}{|l|c|c|c|c|}
\hline \multirow{2}{*}{$\begin{array}{l}\text { Feature of Court } \\
\text { System }\end{array}$} & \multicolumn{3}{|c|}{ Judicial Council Power Index } & $\begin{array}{c}\text { Judicial } \\
\text { Majority on } \\
\text { Council? }\end{array}$ \\
\cline { 2 - 5 } & 1 & 2 & 3 & $40 \%$ \\
\hline $\begin{array}{l}\text { Judicial Review } \\
\text { by ordinary } \\
\text { courts? }\end{array}$ & $9 \%$ & $44 \%$ & $47 \%$ & \\
\hline Common Law? & $8 \%$ & $34 \%$ & $58 \%$ & $42 \%$ \\
\hline
\end{tabular}

To understand the relationship between composition and competence, we divide our sample into three groups using to the power index. We then examine whether an assignment of more extensive powers is associated with a higher percentage of judges on the council. Our results exclude cases for which all information is not available; this leaves seventy-four cases. In addition, we can ignore the small number of councils with purely managerial functions. Councils with the full array of powers have, at the mean, a (bare) majority of judges; councils with reduced powers have a minority of judges. ${ }^{75}$ Using the median rather than mean levels illustrates the difference more starkly: the median council with the full array of powers has sixty percent judges; the median council with reduced powers has twenty-nine percent judges.

\footnotetext{
${ }^{75}$ A difference of means test gives a t-stat of -1.48 ( $85 \%$ confidence level), indicating close to statistical significance.
} 


\section{FIGURE 5}

\section{PERCENTAGE OF JUDGES ON COUNCIL, BY POWER INDEX}

\begin{tabular}{|l|l|l|l|}
\hline $\begin{array}{l}\text { Power } \\
\text { index }\end{array}$ & $\begin{array}{l}\text { Mean \% } \\
\text { of judges }\end{array}$ & $\mathrm{N}$ & $\begin{array}{l}\text { Std. } \\
\text { Deviation }\end{array}$ \\
\hline 1 & .75 & 5 & .28 \\
2 & .39 & 31 & .32 \\
3 & .50 & 38 & .29 \\
Total & .47 & 74 & .31 \\
\hline
\end{tabular}

In short, powers and composition go together, but in two different configurations. When councils are very weak (power index 1), judicial involvement is extensive. When powers are extensive (power index 3), judicial involvement is also relatively high. In the intermediate situation, judicial involvement is lower. We interpret this finding as reflecting the upper right and lower left quadrants of Figure 1. Judicial involvement can be extensive when it does not matter much; but it can also reflect a very powerful and independent judiciary that is extensively involved in politics.

\section{B. Regime Type}

It is possible that regime type can play some role in sorting out the various configurations we observe. We predict that autocracies will feature councils with weak competences (ineffectual council) or strong competences/fewer judges (for greater political control). ${ }^{76}$ For democracies, we predict greater variety, depending on other elements of the institutional configuration. To explore this, we divide constitutions containing provisions on judicial councils into three categories: those that are written in autocracies, those written in established democracies, and those written in transitions between autocracy and democracy. ${ }^{77}$ We use data available from political scientist Carles Boix, who uses other generally available data to make binary characterizations of

\footnotetext{
${ }^{76}$ Logit regression confirms the direction of this relationship, although not at statistically significant levels.

${ }^{77}$ There are no cases in our sample of democracies transitioning to autocracies.
} 
countries as autocracies or democracies in a large time-series. ${ }^{78} \mathrm{We}$ find that the percentage of judges tends to be lower in autocracies rather than democracies, although ttests indicate the difference of means is not quite significant. Still, the crude data indicates a mild tendency of autocracies to distrust judges.

FIGURE 6

PERCENTAGE OF JUDGES ON COUNCIL, BY REGIME TYPE

\begin{tabular}{|l|l|l|l|}
\hline Regime type & Mean \% of judges & N & Std. Deviation \\
\hline Autocracy & .38 & 29 & .30 \\
New Democracy & .48 & 25 & .33 \\
Established & .47 & 30 & .30 \\
democracy & .43 & 84 & .32 \\
Total & .43 \\
\hline
\end{tabular}

\section{Councils and Independence}

Finally, we wish to examine whether the variables of composition and competence correlate with variables such as judicial quality and independence. This is an important question given that judicial councils are offered as a "best practice" to promote judicial independence. As an initial step, we use the Judicial Independence scores produced by Howard and Carey (2004). ${ }^{79}$ They analyzed the U.S. Department of State's Annual Human Rights Reports for a series of years in the 1990s to produce dummy

\footnotetext{
${ }^{78}$ Carles Boix, Democracy and Redistribution (2000); Carles Boix, Constitutions and Democratic Breakdowns, paper presented at Comparative Law and Economics Forum, Chicago (Oct. 2005). For each constitution, the country's autocracy/democracy status was considered for the five years preceding the constitution and immediately afterwards. If the country was rated a democracy in the year of or immediately following the promulgation of the constitution, and had been an autocracy at any time in the five preceding years without an intervening constitution, it was considered to have undergone a transition from autocracy to democracy.

${ }^{79}$ Robert Howard \& Henry A. Carey, Courts and Political Freedom: A Measure of Judicial Independence, 87 JUDICATURE 285 (2004).
} 
variables for individual, collective, and overall judicial independence. We used the last year available (typically 1999). ${ }^{80}$

\section{FIGURE 7}

\section{JUDICIAL INDEPENDENCE (HOWARD-CAREY "INDIVIDUAL INDEPENDENCE”), BY POWER INDEX}

\begin{tabular}{|l|l|l|l|}
\hline $\begin{array}{l}\text { Power } \\
\text { index }\end{array}$ & Mean & $\mathrm{N}$ & $\begin{array}{l}\text { Std. } \\
\text { Deviation }\end{array}$ \\
\hline 1 & .57 & 7 & .53 \\
2 & .55 & 40 & .50 \\
3 & .67 & 51 & .47 \\
Total & .61 & 98 & .49 \\
\hline
\end{tabular}

Here again we see a trend toward more independence with greater competences of the judicial council, suggesting that perhaps councils do increase independence as their proponents assert. There is a potential problem, however: any index that draws on formal structures for the definition of judicial independence raises endogeneity problems. It is possible, for example, that the State Department's assessment is itself affected by whether or not a country has a judicial council. To overcome this problem, we need to examine judicial independence as exists on the ground, rather than relying on formal or structural independence. While this is somewhat difficult to assess, we are fortunate that Professor Voigt and his co-authors have developed separate indices for de facto and de jure independence. ${ }^{81}$ Voigt's de facto index is composed of a number of variables that are likely to impact actual levels of independence, such as the number of times rules

\footnotetext{
${ }^{80}$ We focus on their "individual independence" score, which exhibits much more variance than their collective independence indicator.

${ }^{81}$ Lars Feld \& Stefan Voigt, Economic Growth and Judicial Independence: Cross-Country Evidence Using a new set of Indicators, 19(3) EUR. J. POL. ECON. $497-527$ (2003); Bernd Hayo \& Stefan Voigt, Explaining De Facto Judicial Independence, Marburg Papers on Economics No. 07-2005 (2005), available at http://www.uni-marburg.de/fb02/makro/forschung/gelbereihe/artikel/2005-07-hayo.pdf (last visited Aug. $10,2007)$.
} 
governing appointment or court structure have changed, whether judicial budgets and income have remained constant, whether judges have been removed from office, and instances of non-implementation of judicial decisions. Using this more refined index, it does not appear obvious that de facto judicial independence scores increase with the level of powers for the judicial council.

\section{FIGURE 8}

\section{JUDICIAL INDEPENDENCE DE FACTO (VOIGT), BY POWER INDEX}

\begin{tabular}{|l|l|l|l|}
\hline Power index & Mean & $\mathrm{N}$ & Std. Deviation \\
\hline 1 & .56 & 5 & .24 \\
2 & .51 & 15 & .25 \\
3 & .50 & 26 & .23 \\
Total & .51 & 46 & .23 \\
\hline
\end{tabular}

We also can consider the effect of various features of judicial councils on metrics of judicial independence. Figure 9 presents four models using different dependent variables measuring different aspects of judicial independence and quality. In each case, we examine the effects of two different features of judicial councils widely believed to enhance independence: strong powers and a majority of judges on the council. In no case do either of these indicators approach statistical significance when controlling for common law and GDP. These results are robust to alternative specifications when each feature is included on its own. We find no evidence in support of the presumed relationship between council structure and judicial independence or quality.

A final bit of evidence comes from preliminary analysis of World Bank Rule of Law data on those countries which appear to have adopted a judicial council after 1996. This data shows that more countries suffered a decline in quality of rule of law than an increase. Thirty-nine countries suffered a decline in Rule of Law rating between adoption and 2005, whereas only twenty-seven countries showed an increase. ${ }^{82}$ It seems

\footnotetext{
${ }^{82}$ Data on file with authors.
} 
that the emergence of judicial councils as an international "best practice" for promoting judicial independence and quality may be unjustified.

\section{FIGURE 9: COUNCIL FEATURES AS PREDICTORS OF JUDICIAL INDEPENDENCE}

\begin{tabular}{|c|c|c|c|c|}
\hline $\begin{array}{l}\text { Dependent } \\
\text { Variable }\end{array}$ & Rule of Law Index ${ }^{83}$ & $\begin{array}{c}\text { De Facto } \\
\text { Judicial Independence }^{84}\end{array}$ & Judicial Independence ${ }^{85}$ & $\begin{array}{c}\text { Judicial } \\
\text { Quality/Formalism }^{86}\end{array}$ \\
\hline Constant & -1.08 & 0.41 & 0.31 & 0.25 \\
\hline $\begin{array}{c}\text { Percent of } \\
\text { judges on } \\
\text { council }\end{array}$ & 0.21 & 0.15 & 0.08 & 0.10 \\
\hline $\begin{array}{l}\text { Strong } \\
\text { powers of } \\
\text { council }\end{array}$ & 0.08 & 0.00 & 0.10 & 0.05 \\
\hline $\begin{array}{l}\text { Common } \\
\text { law } \\
\text { dummy }\end{array}$ & $.22 *$ & $-0.16 * *$ & 0.18 & 0.16 \\
\hline $\begin{array}{l}\text { GDP per } \\
\text { capita }\end{array}$ & $.01 * * *$ & $.01 *$ & $.00 * * *$ & $.01 * *$ \\
\hline $\mathrm{R}^{2}$ & .78 & .23 & .45 & .19 \\
\hline
\end{tabular}

the $1 \%$ confidence level

The above results suggest the need to focus on a more dynamic model of council structure. Clearly the effects are not linear. Rather, there is a complex relationship between council structure and political incentives of the various actors at the time of adoption. Ideally, we would be able to model the decision to adopt a judicial council as a

\footnotetext{
${ }^{83}$ World Bank, Worldwide Governance Indicators 1996-2006, available at http://web.worldbank.org/WBSITE/EXTERNAL/WBI/EXTWBIGOVANTCOR/0,,contentMDK:2077116 5 menuPK:1866365 pagePK:64168445 piPK:64168309 theSitePK:1740530,00.html.

${ }^{84}$ See supra note 81.

${ }^{85}$ See Howard \& Carey, supra note 79.

${ }^{86}$ Simeon Djankov et al., Courts: The Lex Mundi Project, CEPR Discussion Papers 3344 (2002).
} 
product of the political factors we identify. However, we face two daunting data challenges that prevent us from specifying such a model. First, we would need comprehensive data on the judicial appointment systems of all countries, including those without a council, before and after the adoption. Although Hanssen was able to gather some such data in the United States, we have found no comparable sources across a large number of countries. ${ }^{87}$ Second, we would need refined indicators of political variation across countries over time. We are not convinced that any one indicator would serve as an ideal proxy for the myriad conditions that lead countries to adopt judicial councils. Our preliminary conclusion, then, is that there is no evidence that judicial councils promote independence.

\section{Conclusion}

This Article is a first examination of judicial councils, a relatively new institution associated with attempts to enhance judicial independence. We began by providing a comprehensive view of common-law judicial appointment commissions and civil-law high judicial councils. We have argued that the different designs aim at achieving the appropriate balance between independence and accountability in the face of two recurrent phenomena: the politicization of the judiciary and the judicialization of politics. We provide a typology of judicial councils by looking at two crucial elements, composition and competences, and test their interactions.

Our empirical observation of patterns of institutional design show that competence and composition interact in complex ways to respond to particular institutional problems. We also found little evidence in favor of the widespread assumption that councils increase quality or independence in the aggregate. Therefore, we emphasize the complexity of the role of a judicial council and reject the simplistic view that importing or transplanting certain types of judicial council is likely to have a decisive impact on the quality of the judiciary. We thus reject the view of international

${ }^{87}$ Cf. Hannsen, supra note 47. 
organizations that assert that judges should always and everywhere form the majority of members on the Council. ${ }^{88}$

Our framework also explains why it is that councils persist as institutions. Because they involve actors from multiple different arenas, the council itself promises that no one institution can easily dominate the judiciary. The councils, once created, provide an arena for competition and the eternal struggle to calibrate independence and accountability. We thus predict that councils themselves will frequently become the targets of institutional reform, as examples from Italy, Brazil and elsewhere demonstrated. $^{89}$ We also can understand why they have been widely adopted, notwithstanding little support for claims that they enhance independence: councils allow a wide number of stakeholders to participate in discussions of judicial governance.

Finally, we introduce the notion of the politically accountable but strong judiciary. In many ways, this ideal type is more desirable than the conventional view that judicial independence is an unqualified good. Those who emphasize judicial independence too often do not articulate the need for accountability, which provides the crucial other side of the proverbial coin.

These findings have important implications for the ongoing debate on judicial appointments in the United States. Rather than assume that merit commissions, the American counterpart to judicial councils, always enhance independence, scholars should conduct more thorough empirical research to understand the precise determinants of independence and accountability. Our case studies suggest that these determinants are highly context-specific and not susceptible to one-size-fits-all solutions.

\footnotetext{
${ }^{88}$ Autheman \& Elena, supra note 26.

${ }^{89}$ Autheman \& Elena, supra note 26, provide a very interesting report of survey data from five Central American countries. Respondents in those countries that had a judicial council reported that the Council had had a negative impact on judicial independence. Respondents in those countries that did not have a judicial council felt that adopting a judicial council would increase judicial independence. Id. at 4 . These two results are not contradictory from our point of view. First, the two sets of countries have different starting places and are likely to vary systematically. Second, the countries that have adopted judicial councils may have done so to enhance accountability rather than independence, in which case, respondents are observing a successful institution.
} 


\section{APPENDIX: DATA ON JUDICIAL COUNCILS}

Country

Albania

Algeria

Andorra

Angola

Argentina

Armenia

Bahamas

Bahrain

Bangladesh

Barbados

Belgium

Belize

Benin

Bolivia

Bosnia-Herzegovina

Botswana

Brazil

Bulgaria

Burkina Faso

Burundi

Cameroon

Cape Verde

Central African

Republic

Chad

Chile

China

Colombia

Comoros

Costa Rica

Cote D'Ivoire

Croatia

Cyprus

Democratic Republic

of Congo

Dominica

East Timor

Ecuador

Egypt

El Salvador

Equatorial Guinea

Eritrea

Ethiopia

Fiji

France

\begin{tabular}{|c|c|c|}
\hline $\begin{array}{l}\text { Number } \\
\text { of } \\
\text { Members }\end{array}$ & $\begin{array}{l}\text { Proportion } \\
\text { of Judges }\end{array}$ & $\begin{array}{l}\text { Power } \\
\text { Index }\end{array}$ \\
\hline 15 & 0.67 & 3 \\
\hline . & & 3 \\
\hline 5 & 0.2 & 2 \\
\hline 19 & 0.58 & 3 \\
\hline . & 0.25 & 2 \\
\hline 14 & 0.64 & 3 \\
\hline . & . & 3 \\
\hline 3 & 1 & 2 \\
\hline 5 & 0.2 & 3 \\
\hline . & 0.5 & 2 \\
\hline 4 & 0.25 & 3 \\
\hline . & . & 2 \\
\hline . & 0.2 & 2 \\
\hline 8 & 0 & . \\
\hline 3 & 0.5 & 3 \\
\hline 5 & 1 & 1 \\
\hline 25 & 0.52 & 3 \\
\hline 15 & 0.47 & $\begin{array}{l}2 \\
3\end{array}$ \\
\hline . & . & 3 \\
\hline 9 & 0.33 & 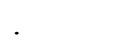 \\
\hline . & . & . \\
\hline . & . & 3 \\
\hline . & 0 & . \\
\hline 13 & 1 & 3 \\
\hline . & . & . \\
\hline . & 0.6 & 2 \\
\hline . & . & 2 \\
\hline . & . & 3 \\
\hline 8 & 1 & 3 \\
\hline . & & 2 \\
\hline 5 & 0.29 & 2 \\
\hline 5 & 0.4 & 3 \\
\hline 8 & 0.13 & 3 \\
\hline 6 & 0 & 2 \\
\hline 7 & 0 & \\
\hline . & . & 2 \\
\hline$\cdot$ & & 3 \\
\hline 3 & 0.33 & 3 \\
\hline 17 & 0.46 & 3 \\
\hline
\end{tabular}




\begin{tabular}{|c|c|c|}
\hline Gabon & 7 & 0.57 \\
\hline Gambia & 9 & 0.38 \\
\hline Guatemala & 5 & 0.6 \\
\hline Ghana & 5 & 0.8 \\
\hline Greece & 5 & 1 \\
\hline Guyana & & \\
\hline Hungary & & 1 \\
\hline Indonesia & & 0 \\
\hline Iraq & 3 & 1 \\
\hline Israel & 9 & 0.33 \\
\hline Italy/Sardinia & & 0.6 \\
\hline Jamaica & 6 & 0.33 \\
\hline Kazakhstan & & 0 \\
\hline Kenya & 5 & 0.6 \\
\hline Kuwait & & \\
\hline Latvia & & \\
\hline Lebanon & 15 & 0.53 \\
\hline Lesotho & 4 & 0.25 \\
\hline Lithuania & & \\
\hline Macedonia & 7 & 0 \\
\hline Madagascar & & \\
\hline Malawi & & \\
\hline Malaysia & 2 & 0 \\
\hline Mali & & \\
\hline Malta & 10 & 0.5 \\
\hline Marshall Islands & 3 & 0.33 \\
\hline Mauritius & 4 & 0.5 \\
\hline Mexico & 4 & 1 \\
\hline Moldova & 11 & 0.55 \\
\hline Mongolia & & \\
\hline Morocco & & 0.86 \\
\hline Mozambique & 16 & 0.56 \\
\hline Namibia & 4 & 0.25 \\
\hline Nepal & 5 & 0.6 \\
\hline Niger & & \\
\hline Nigeria & 3 & 1 \\
\hline Pakistan & 5 & 1 \\
\hline Palau & 7 & 0.14 \\
\hline Panama & 8 & 0.63 \\
\hline Papua New Guinea & 5 & 0.4 \\
\hline Paraguay & 8 & 0.13 \\
\hline Peru & 7 & 0.14 \\
\hline Philippines & & 0.22 \\
\hline Poland & 15 & \\
\hline Portugal & 17 & 0.47 \\
\hline Republic of Congo & & \\
\hline Romania & 19 & 0.79 \\
\hline Rwanda & & 1 \\
\hline Saint Vincent & & \\
\hline Samoa & 3 & 0.33 \\
\hline
\end{tabular}




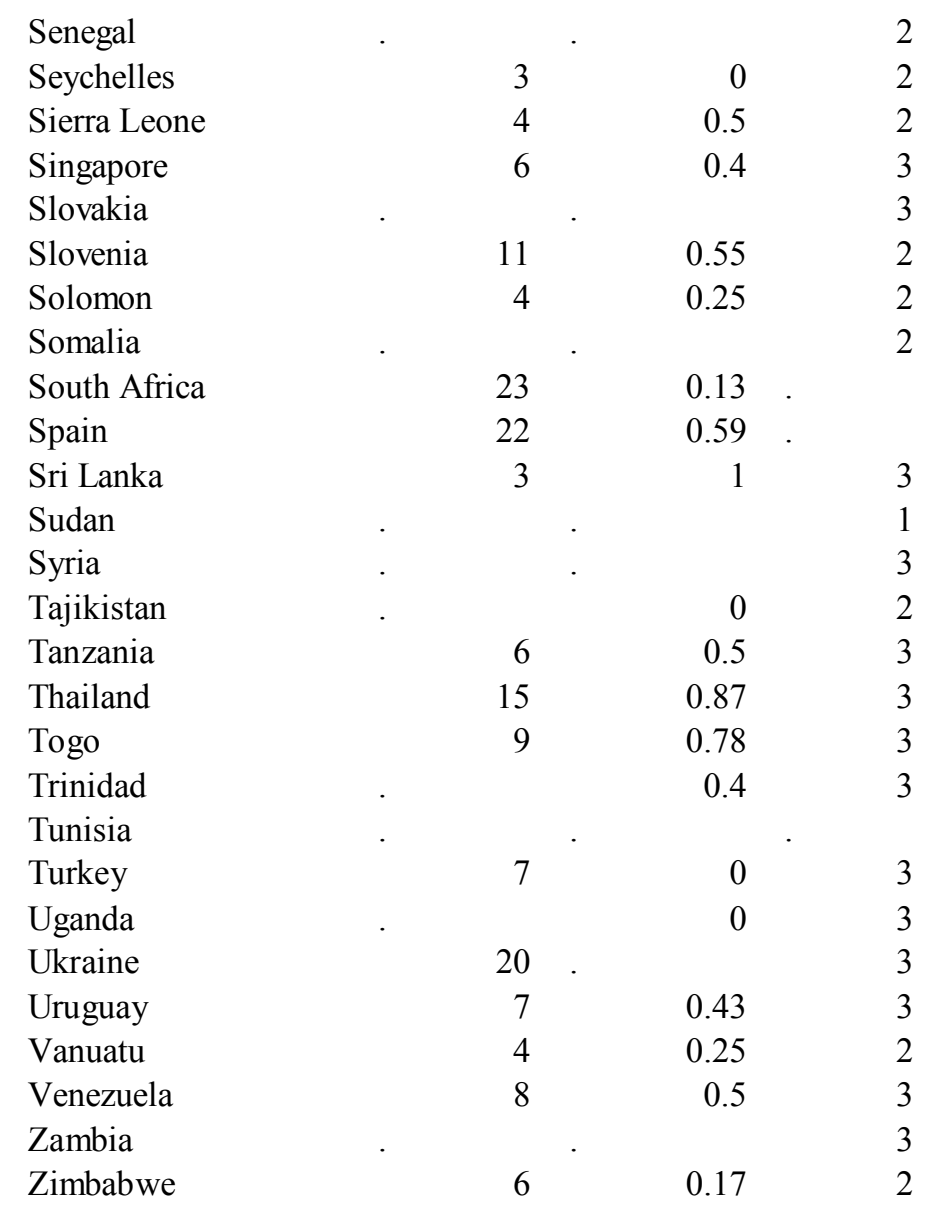

Key: Power Index has value 1 for purely administrative functions, value 2 for involvement in appointments, and value 3 for roles in both appointment and discipline, removal or promotion of judges. 
Readers with comments should address them to:

Professor Tom Ginsburg

University of Chicago Law School

1111 East 60th Street

Chicago, IL 60637

tginsburg@uchicago.edu 


\section{Chicago Working Papers in Law and Economics (Second Series)}

For a listing of papers 1-399 please go to Working Papers at http://www.law.uchicago.edu/Lawecon/index.html

400. Shyam Balganesh, Foreseeability and Copyright Incentives (April 2008)

401. Cass R. Sunstein and Reid Hastie, Four Failures of Deliberating Groups (April 2008)

402. M. Todd Henderson, Justin Wolfers and Eric Zitzewitz, Predicting Crime (April 2008)

403. Richard A. Epstein, Bell Atlantic v. Twombly: How Motions to Dismiss Become (Disguised) Summary Judgments (April 2008)

404. William M. Landes and Richard A. Posner, Rational Judicial Behavior: A Statistical Study (April 2008)

405. Stephen J. Choi, Mitu Gulati, and Eric A. Posner, Which States Have the Best (and Worst) High Courts? (May 2008)

406. Richard H. McAdams and Janice Nadler, Coordinating in the Shadow of the Law: Two Contextualized Tests of the Focal Point Theory of Legal Compliance (May 2008, revised October 2008)

407. Cass R. Sunstein, Two Conceptions of Irreversible Environmental Harm (Mary 2008)

408. Richard A. Epstein, Public Use in a Post-Kelo World (June 2008)

409. Jonathan R. Nash, The Uneasy Case for Transjurisdictional Adjudication (June 2008)

410. Adam B. Cox and Thomas J. Miles, Documenting Discrimination? (June 2008)

411. M. Todd Henderson, Alan D. Jagolinzer, and Karl A. Muller, III, Scienter Disclosure (June 2008)

412. Jonathan R. Nash, Taxes and the Success of Non-Tax Market-Based Environmental Regulatory Regimes (July 2008)

413. Thomas J. Miles and Cass R. Sunstein, Depoliticizing Administrative Law (June 2008)

414. Randal C. Picker, Competition and Privacy in Web 2.0 and the Cloud (June 2008)

415. Omri Ben-Shahar, The Myth of the “Opportunity to Read” in Contract Law (July 2008)

416. Omri Ben-Shahar, A Bargaining Power Theory of Gap-Filling (July 2008)

417. Omri Ben-Shahar, How to Repair Unconscionable Contracts (July 2008)

418. Richard A. Epstein and David A. Hyman, Controlling the Costs of Medical Care: A Dose of Deregulation (July 2008)

419. Eric A. Posner, Erga Omnes Norms, Institutionalization, and Constitutionalism in International Law (August 2008)

420. Thomas J. Miles and Eric A. Posner, Which States Enter into Treaties, and Why? (August 2008)

421. Cass R. Sunstein, Trimming (August 2008)

422. Cass R. Sunstein, Second Amendment Minimalism: Heller as Griswold (August 2008)

423. Richard A. Epstein, The Disintegration of Intellectual Property (August 2008)

424. John Bronsteen, Christopher Buccafusco, and Jonathan Masur, Happiness and Punishment (August 2008)

425. Adam B. Cox and Thomas J. Miles, Judicial Ideology and the Transformation of Voting Rights Jurisprudence (August 2008)

426. Daniel Abebe and Jonathan S. Masur, A Nation Divided: Eastern China, Western China, and the Problems of Global Warming (August 2008)

427. William Birdthistle and M. Todd Henderson, One Hat Too Many? Investment Desegregation in Private Equity (August 2008)

428. Irina D. Manta, Privatizing Trademarks (abstract only) (September 2008)

429. Paul J. Heald, Testing the Over- and Under-Exploitation Hypothesis: Bestselling Musical Compositions (1913-32) and Their Use in Cinema (1968-2007) (September 2008)

430. M. Todd Henderson and Richard A. Epstein, Introduction to “The Going Private Phenomenon: Causes and Implications” (September 2008)

431. Paul Heald, Optimal Remedies for Patent Infringement: A Transactional Model (September 2008)

432. $\quad$ Cass R. Sunstein, Beyond Judicial Minimalism (September 2008)

433. Bernard E. Harcourt, Neoliberal Penality: The Birth of Natural Order, the Illusion of Free Markets (September 2008) 
434. Bernard E. Harcourt, Abolition in the U.S.A. by 2050: On Political Capital and Ordinary Acts of Resistance (September 2008)

435. Robert Cooter and Ariel Porat, Liability for Lapses: First or Second Order Negligence? (October 2008)

436. Ariel Porat, A Comparative Fault in Defense Contract Law (October 2008)

437. Richard H. McAdams, Beyond the Prisoners' Dilemma: Coordination, Game Theory and the Law (October 2008)

438. Dhammika Dharamapala, Nuno Garoupa, and Richard H. McAdams, Belief in a Just World, Blaming the Victim, and Hate Crime Satatutes (October 2008)

439. M. Todd Henderson, The Impotence of Delaware's Taxes: A Short Response to Professor Barzuza's Delaware's Compensation (October 2008)

440. Richard McAdams and Thomas Ulen, Behavioral Criminal Law and Economics (November 2008)

441. Cass R. Sunstein, Judging National Security post-9/11: An Empirical Investigation (November 2008)

442. Eric A. Posner and Adrian Vermuele, Crisis Governance in the Administrative State: 9/11 and the Financial Meltdown of 2008 (November 2008)

443. Lee Anne Fennell, Adjusting Alienability (November 2008)

444. Nuno Garoupa and Tom Ginsburg, Guarding the Guardinas: Judicial Councils and Judicial Independence (November 2008) 